A N N A LES

UNIVERSITATIS MARIAE CURIE-SKŁODOWSKA LUBLIN - POLONIA

VOL. XVI, 1-2

SECTIO L 2018

Instytut Muzyki Uniwersytetu Marii Curie-Skłodowskiej

Renata Gozdecka

\title{
Miejsca ojczyste w muzyce kompozytorów hiszpańskich XIX-XX wieku. Propozycja dydaktyczna
}

Native Places in the Music of Spanish Composers of the 19th-20th centuries.

A Didactic Suggestion

Kultura Hiszpanii jest melanżem różnych kultur i skarbów historycznych, które na przestrzeni wieków, od starożytnych malowideł naskalnych w grotach Altamiry po awangardę artystyczną XX wieku, rozwijały się na Półwyspie Iberyjskim; oddziałując na siebie, stworzyły mozaikę o niezliczonym bogactwie kolorów. Wszak wszystkie najważniejsze nurty w światowej kulturze i sztuce znalazły swoje odzwierciedlenie w twórczości wybitnych artystów hiszpańskich w tym kompozytorów, którzy nadali swym dziełom uniwersalny wymiar.

Odrodzenie muzyki hiszpańskiej - zgodnie z romantycznym impulsem pobudzającym europejskie szkoły narodowe, polegającym na zwróceniu się ku rodzimemu folklorowi - datuje się na ostatnie lata XIX wieku. To właśnie w roku 1891 ceniony działacz i zbieracz hiszpańskiego folkloru Filip Pedrell wystosował postulat powrotu do muzyki ludowej i chlubnych tradycji hiszpańskiej muzyki artystycznej z XV-XVII wieku. Folklor muzyczny Hiszpanii, niezwykle bogaty i różnorodny, cechują urozmaicona, żywa rytmika, wyróżniająca się stosowaniem synkop (nawet w drobnych wartościach rytmicznych), triol, rytmów punktowanych i zmienność akcentów. W hiszpańskiej muzyce uwidacznia się silny związek śpiewu z żywiołowymi tańcami oraz towarzyszącą im grą na instrumentach, 
takich jak gitara, tamburyn, kastaniety, które są niezwykle charakterystyczne i wyróżniają muzykę tego narodu na tle muzyki innych europejskich krajów. Hiszpania to wreszcie pieśniowo-taneczny styl flamenco - zakorzeniony w folklorze południa kraju, współtworzący kulturową specyfikę kraju i do dziś wywołujący emocje każdej widowni ${ }^{1}$.

W twórczości muzycznej hiszpańskich kompozytorów dostrzegamy dość wyraźnie wyodrębniony nurt dzieł, dla których źródła inspiracji wyłoniły się z geograficzno-kulturowych toposów ojczystego kraju. W tytułach tego typu utworów pojawiają się nazwy regionów Hiszpanii (m.in. Asturia, Kastylia, Aragonia, Katalonia, Baskonia, Andaluzja), jej miast (np. Granada, Kadyks, Ronda, Jerez, Kordoba), nierzadko w ścisłym powiązaniu z różnymi znaczącymi fenomenami historyczno-kulturowymi i artystycznymi (np. malarstwem Francisco Goi). Uwagę naszą przyciągną kompozycje czołowych twórców hiszpańskich z końca XIX i początku XX wieku: Francisco Tárregi (1852-1909), Isaaca Albéniza (1860-1909), Enrique Granadosa (1867-1916), Manuela de Falli (1876-1946) i Joaquina Turiny (1882-1949). Zaznaczmy, że będzie to jedynie zasygnalizowanie wskazanego zjawiska, głównie dla celów edukacyjnych; jego pełne i wszechstronne przedstawienie wymagałoby obszerniejszego studium.

\section{Francisco Tárrega}

Kompozycją nawiązującą do miejsca na południu Hiszpanii, wyrażającą zachwyt nad pięknem i oryginalnością architektury jest jedna z trzydziestu miniatur gitarowych Francisco Tárregi ${ }^{2}$ - Recuerdos de la Alhambra [Wspomnienia $z$ Alhambry] $]^{3}$. Tytuł utworu odsyła do zamku w Granadzie - jedynego zachowanego pomnika wielkiego dorobku artystycznego Granady z czasów islamskich. Rozmach i przepych zespołu pałacowego, równocześnie wytworna subtelność i wspaniałość jego proporcji, sytuują zamek w panteonie nieoficjalnych cudów świata. Jest on szczytowym osiągnięciem muzułmańskiej wyobraźni, artyzmu,

${ }^{1}$ Por. B. Rudnicki, Podróże marzeń. Hiszpania, Warszawa 2005, s. 101.

${ }^{2}$ W. Berny-Negrey, Tárrega y Eixea Francisco, [w:] Encyklopedia Muzyczna PWM. Część biograficzna, red. E. Dziębowska, t. 11, Kraków 2009, s. 37.

${ }^{3}$ Francisco Tárrega uważany jest za wirtuoza gitary, który bardzo umiejętnie wykorzystywał możliwości instrumentu. Jego grę cechowały blask i precyzja artykulacji. Kompozycje Tárregi nadal pozostają $w$ repertuarze pedagogicznym, a jego miniatury, czerpiące niekiedy z tradycji hiszpańskiej i mozarabskiej, odznaczają się elegancją i melodycznym wdziękiem. Niektóre z nich - jak właśnie Recuerdos de la Alhambra - zachowały do naszych czasów szeroką popularność. Do przyjaciół kompozytora należeli m.in. Isaac Albéniz i Enrique Granados. Zob. ibid., s. 37. 
doskonałym wyrazem wysoko rozwiniętej kultury ${ }^{4}$. W konstrukcji całego zespołu wykorzystano efekt przepływających strug wody, przemierzających różne miejsca zamku - wyznaczone przez rozmaite konstrukcje architektoniczne w postaci kanałów, przepływów, sztucznych rzek. Wyróżniającym się elementem jest dziedziniec z Fontanną Lwów, z którego płynie woda przez większość pomieszczeń zamku do ogrodów, zbiorników, fontann, przepuszczana przez płytkie kanały w posadzkach. Wszystko to razem stanowi do dziś źródło ochładzania atmosfery gorącego wnętrza, pozostaje jednocześnie oryginalnym rozwiązaniem architektonicznym o symboliczno-historycznej wymowie.

Zastosowana przez Tárregę we Wspomnieniach z Alhambry gitarowa technika tremolo, przypominająca nieco brzmienie mandoliny, współtworzy oryginalną strukturę kompozycji, opartej od strony techniczno-fakturalnej na wielokrotnym powtarzaniu szarpnięć struny trzema palcami, co u słuchaczy wywołuje złudzenie jednego długiego tonu. Przy audytywnej percepcji - z uwagi na harmoniczne nakładanie się dźwięków gitary - można odnieść wrażenie, że muzykę tę wykonuje dwóch gitarzystów ${ }^{5}$.

\section{Isaac Albéniz}

Albéniz zaznaczył swoją obecność w historii muzyki hiszpańskiej nie tylko karierą pianistyczną, rozpoczętą już w młodym wieku, ale przede wszystkim twórczością kompozytorską, która znalazła swoje odbicie w wielu dziełach powstałych w ciągu całego życia twórcy ${ }^{6}$. Był jednym z najwybitniejszych wirtuozów swojej epoki. Pod koniec XIX stulecia styl kompozytora odznaczał się już dużą indywidualnością, zwłaszcza w utworach fortepianowych o tematyce hiszpańskiej. Najciekawszymi z wczesnych kompozycji Isaaca Albéniza są dwie Suity hiszpańskie. Pierwsza z nich to ośmioczęściowa suita op. 47, w całości poświęcona

\footnotetext{
${ }^{4}$ Rudnicki, op. cit., s. 211.

${ }^{5}$ R. Gozdecka, Obraz żywiołu wody w muzyce i sztukach plastycznych. Przyczynek do edukacji interdyscyplinarnej, „Annales Univeristatis Mariae Curie-Skłodowska, Sectio L, Artes” 10: 2012, nr 1, s. 150.

${ }^{6}$ W 1867 roku Albéniz, mający siedem lat, rozpoczął naukę w Paryżu, którą kontynuował w Madrycie. Trzy lata później (po ucieczce z domu) koncertował w różnych prowincjach Hiszpanii. W roku 1972 (po powtórnej ucieczce) wyjechał do Ameryki Południowej. Koncertował w wielu krajach Europy, także na Kubie i w USA. Pianistyczny i kompozytorski talent Albéniza rozwinął się pod wpływem spotkań z Ferencem Lisztem, duże znaczenie miały też kontakty z Filipem Pedrellem, twórcą narodowej szkoły hiszpańskiej i scenicznych zarzueli (jego ideę rozwinęli, poza Albénizem, uczniowie, m.in. Enrique Granados i Manuel de Falla). Por. Z. Helman, Albéniz, [w:] Encyklopedia Muzyczna PWM. Część biograficzna, red. E. Dziębowska, t. 1, Kraków 1979, s. 24.
} 
miastom lub prowincjom kraju. Cykl tworzą kolejno: Granada, Cataluña, Sevilla, Cádiz, Asturias, Aragon, Castilla i Cuba ${ }^{7}$. Granada, pierwsza i najstarsza część suity, powstała pod wpływem cante flamenco; charakteryzuje ją linia melodyczna usytuowana w niskim rejestrze. Katalonia odwołuje się do folkloru prowincji, z której pochodził Albéniz; rozbrzmiewa w niej rytmika corrandy, charakterystycznego tańca katalońskiego w metrum 6/8. Sevilla z kolei - w której skrajne partie rozbrzmiewają z niezwykłą energią w kontraście wobec środkowej fazy stanowi rodzaj religijnej pieśni saeta. W części czwartej suity, Cádiz, z charakterystycznymi basowymi triolami, ożywiającymi całość kompozycji, pojawia się nostalgiczny motyw w tonacji molowej. W Asturii dźwięki fortepianu przypominają gitarowe brzmienie - są ostre i regularnie przerywane mocno akcentowanym akordem; część ta wyrasta bezpośrednio z południowo hiszpańskiego cante jondo i jest andaluzyjską pieśnią typu solear ${ }^{8}$. Aragonia utrzymana jest w pogodnym brzmieniu tonacji durowej, Kastylia natomiast rozbrzmiewa w żywiołowym rytmie tańca pochodzenia mauretańskiego. Ostatnia część suity, zatytułowana Cuba, skomponowana w rytmie tanga, nawiązuje do wyspy na Morzu Karaibskim, która do 1886 roku należała do Hiszpanii.

Kolejnym cyklem utworów Albéniza inspirowanym ojczystym krajem jest España op. 165 z 1890 roku, składająca się z sześciu części. Jedna z nich nosi nazwę Malagueña, która przywołuje miasto Málaga i równocześnie określa trzy typy muzyki hiszpańskiej z prowincji Málaga i Murcja. Inne kompozycie fortepianowe Albéniza to: dwa Dances espagnoles op. 164, Serenata española op. 181 oraz Chants d'Espagne op. 232, z częścią zatytułowaną Cordoba.

Dojrzałość artystyczną osiągnął Albéniz dopiero w ostatnim okresie twórczości, czego reprezentatywnym dokonaniem stała się suita fortepianowa Iberia. Dzieło skomponowane zostało w latach 1905-1909 i zgrupowane w czterech zeszytach, w których Albéniz zamieścił po trzy kompozycje. Cykl otwiera Evocación z elementami hiszpańskiego tańca ludowego fandango oraz tańca jota pochodzącego z Aragonii i wykonywanego z towarzyszeniem kastanietów. Część druga, El Puerto, przywołuje miasto portowe El Puerto de Santa Maria w południowo-zachodniej Hiszpanii (region Andaluzja, prowincja Kadyks). Zeszyt pierwszy zamyka Fête-dieu à Seville - utwór nawiązujący do procesji przemierzających ulice Sewilli z okazji Święta Bożego Ciała. W muzyce tej słychać marszowe brzmienia oraz andaluzyjski wokalny styl flamenco cante jondo $\mathrm{z}$ akompaniamentem

${ }^{7}$ Jak czytamy w biograficznej monografii poświęconej Albénizowi, pierwotną wersję suity tworzyły tylko cztery utwory: Granada, Katalonia, Sevilla, Kuba, pozostałe zaś - Kadyks, Asturia, Aragonia, Kastylia - powstały nieco później i zostały włączone do suity już po śmierci Albéniza, prawdopodobnie przez wydawcę. Zob. M. Bzowska, Albeniz, Kraków 1964, s. 21.

${ }^{8}$ Zob. ibid., s. 24. 
gitar flamenco. Zeszyt drugi tworzą trzy kompozycje opatrzone nazwami miast Andaluzji: Rondeña (miasto w prowincji Malaga z monumentalnym stumetrowym mostem), Almería (miasto w południowo-wschodniej Hiszpanii) oraz Tria$n a$ (cygańska dzielnica w Sewilli). Środkową część Iberii otwiera El Albaicín, utwór przywołujący swoim tytułem arabską dzielnicę w centrum Granady. Kolejne ogniwa tej części to El Polo i Lavapiés (nazwa dzielnicy Madrytu). Ostatnią, czwartą część Iberii tworzą trzy kompozycje: Málaga (miasto w Andaluzji), Jerez (miasto Andaluzji w prowincji Kadyks) oraz Eritaña (nazwa popularnej ówcześnie karczmy na obrzeżach Sewilli).

Z innych „geograficznych” kompozycji Albéniza wymienić należy jeszcze II Suitę Española (w skład której wchodzą dwie części: Zaragoza - nawiązująca do miasta Saragossa w północno-wschodniej Hiszpanii, i Sevilla) oraz barkarolę Mallorca, biorącą swą nazwę od największej w archipelagu Balearów wyspy hiszpańskiej na Morzu Śródziemnym.

Wśród kompozycji orkiestrowych Albéniza znajdują się Rapsodia española op. 70 na fortepian i orkiestrę (1887) i poemat symfoniczny Catalonia, pochodzący z trzyczęściowej suity Scénes symphoniques catalanes (1899).

Isaac Albéniz nawiązywał w swojej twórczości do ludowej i popularnej muzyki hiszpańskiej, nigdy jednak nie stosował wiernych cytatów; wprowadzał natomiast rytmy różnych tańców hiszpańskich, jak jota (Aragon w I Suicie hiszpańskiej), sequidilla (Chants d'Espagne), malaguena (Malaga w Iberii), zortzico (w suicie España) oraz rondeny (Rondeña w Iberii) ${ }^{9}$. Warto zacytować w tym miejscu Zofię Helman:

„Cechy twórczości Albéniza wynikające ze stylizacji muzyki ludowej w znacznym stopniu przyczyniły się do wzbogacenia i urozmaicenia środków muzyki XIX w. zwłaszcza w zakresie rytmu, wzbogacił także środki harmoniczno-tonalne [...], stosował kontrastową dynamikę, zróżnicowaną artykulację, efekty wybrzmiewania akordów przypominające już fakturę Debussy'ego. Wiele nowych chwytów fakturalnych Albéniza wynikało z naśladowania brzmienia gitary"10.

Albéniz zapoczątkował w muzyce hiszpańskiej kierunek narodowy, kontynuowany następnie przez innych kompozytorów XIX wieku, takich jak Enrique Granados, Manuel de Falla czy Joaquin Turina.

\footnotetext{
${ }^{9}$ Helman, op. cit., s. 24.

${ }^{10}$ Ibid.
} 


\section{Enrique Granados}

Sława Granadosa wykroczyła daleko poza granice XIX-wiecznej Hiszpanii, bo aż za ocean. Styl muzyczny kompozytora ukształtował się wprawdzie pod wpływem folkloru hiszpańskiego, ale - jak zauważa Wiesława Berny-Negrey obecność czynnika folklorystycznego jest w jego twórczości nieco zawoalowana:

„Sięgając często do rytmiki tańców ludowych, nie eksponuje jej jako pierwszoplanowego elementu muzycznego, a kontrapunktując rytmikę swobodnymi wątkami melodycznymi w różnych planach uzyskuje incydentalne i każdorazowo zmienne efekty o charakterze polirytmicznym. [...] Harmonika Granadosa jest w pierwszym rzędzie pochodną techniki kontrapunktycznej o folklorystycznym, nie klasycznym rodowodzie" ${ }^{" 1}$.

Tego rodzaju język muzyczny przyczynił się do powstania oryginalnych dzieł, takich jak: Danzas españolas, skomponowanych w latach 1892-1900, Escenas romanticas - zbioru 12 pieśni Colleción de tonadillas, wzorowanych na śpiewach hiszpańskich z XVIII wieku, oraz oryginalnym, będącym kulminacją twórczości Granadosa, dziełem Goyescas, w którym kompozytor zespolił muzykę z malarstwem ważnego dla kultury hiszpańskiej artysty, Francisco Goi (1746-1828). Cykl impresyjnych poematów fortepianowych oddaje fascynację Granadosa geniuszem wyobraźni twórczej Goi i jego spojrzeniem na świat. Granados ponadto, jako malarz i kolekcjoner obrazów, chciał odtworzyć w muzyce klimat płócien Goi, w których dostrzegał wspaniałą przeszłość Hiszpanii, zgodnie z nurtem romantyzmu idealizującym historię, choć w sferze środków muzycznych - jak zauważa Berny-Negrey - dzieło wybiega już poza romantyzm ${ }^{12}$. Kompozycję tworzy osiem części stanowiących suitę fortepianową, będącą bazą dla późniejszej opery ${ }^{13}$. Wpływ na inspirację malarstwem Goi miała znajomość Granadosa z pisarzem Fernando Periquetem (1873-1940), dzięki której nawiązał on do twórczości Goi, umiejętnie oddającego esencję hiszpańskiego stylu. Obrazy ukazywały atmosferę Madrytu, ludzi i szczegóły z ich życia. Granados wyjawił swoją fascynację w liście z 1910 roku:

${ }^{11}$ W. Berny-Negrey, Granados y Campiña, [w:] Encyklopedia Muzyczna PWM. Część biograficzna, red. E. Dziębowska, t. 3, Kraków 2009, s. 443.

${ }^{12}$ Ibid.

${ }^{13}$ Cykl fortepianowy Goyescas, powstały w 1911 roku, odniósł wielki sukces we Francji, co zaowocowało zamówieniem na operę na nim opartą. Z powodu trwającej pierwszej wojny światowej prawykonanie opery Goyescas odbyło się nie w Operze Paryskiej, jak pierwotnie planowano, lecz 1916 roku w Metropolitan Opera w Nowym Jorku. W drodze powrotnej do Hiszpanii Granados poniósł śmierć (wraz z żoną Amparo Gal) na pokładzie angielskiego statku Sussex, storpedowanego przez niemiecką łódź podwodną. Zob. ibid., s. 443. 
„[...] zakochałem się w psychologii Goi i jego palecie kolorów, tej bladoróżowości policzków kontrastującej z koronką i kruczoczarnym aksamitem, tych jaśminowo białych dłoni, kolorów niczym perłowa macica"14.

Angielski krytyk, Ernest Newman, opisał Granadosa Goyescas jako „najznakomitszą muzykę fortepianową naszych czasów, wspaniały kąsek dla palców”, dający artyście i słuchaczowi

,$[\ldots]$ zmysłowe uczucie przebierania palcami przez masy pełnych kolorów kryształów. Zaiste, dzieło jest niesamowitym wyzwaniem dla artysty - skomplikowane pasaże i bogata tekstura wymagają poziomu wirtuoza techniki pianistycznej”'15.

Jednym z cykli malarskich Francisco Goi ${ }^{16}$, które urzekły kompozytora i stały się źródłem inspiracji dla wybranych utworów fortepianowych z suity Goyescas, jest najbardziej znany, pierwszy wielki cykl graficzny, uważany za arcydzieło sztuki europejskiej - Los Caprichos [Kaprysy]. Kaprysy powstały w latach 1797-1798, a cały cykl składa się z osiemdziesięciu grafik wykonanych w technice miedziorytu. Grafiki te są satyrą na społeczeństwo hiszpańskie z końca XVIII wieku, odnoszą się zwłaszcza do szlachty, urzędników i kleru - osób nadających ton państwu i społeczeństwu hiszpańskiemu; w ten sposób Goya podzielił się swoimi przemyśleniami na temat wad społeczeństwa. Lecz Kaprysy - jak czytamy u Marii Poprzędzkiej -

„To nie tylko obyczajowa satyra. To także wybuch anarchicznej wyobraźni udręczonej chorobą i postępującą izolacją od świata, która wypełniła plansze tłumem stworów ludzkich o zwierzęcych pyskach, nietoperzami o ludzkich twarzach, czarownicami, zjawami cmentarnymi, sennymi majakami i koszmarami"'17.

Część pierwsza z ośmiu kompozycji muzycznego cyklu Goyescas Granadosa to Los requiebros [Pochlebstwo] - kompozycja bezpośrednio nawiązująca do kaprysu Goi numer 5: Capricho, Tal para qual [Jedno warte drugiego]. Grafika przestawia parę tancerzy (tańczą taniec jota, wywodzący się z regionu historycznego Goi, tj.

\footnotetext{
${ }^{14}$ D. Riva, [komentarz], Granados, Goyescas (Suite for piano), płyta CD, Naxos 1998.

${ }^{15}$ Ibid.

${ }^{16}$ Goya jest twórcą trzech późniejszych wielkich cykli graficznych: Los Desastres [Okropności wojny] - 82 ryciny), La Tauromaquia [Walki byków] - 40 rycin, Los Proverbios [Przystowia] - 22 ryciny.

${ }^{17}$ Cykl rycin opublikowany został w 1799 roku, od 1793 roku Goya chorował, wskutek czego stracił słuch, por. Francisco Goya. Los Caprochos. Kaprysy, Katalog wystawy, Muzeum Okręgowe w Toruniu, słowo wstępne M. Poprzędzka, Toruń 1998, s. 8.
} 
Pobrane z czasopisma Annales L - Artes http://artes.annales.umcs.pl

Data: 26/04/2023 15:49:07

Aragonii) oraz dwie nieopodal siedzące starsze kobiety. Goya, komentujący swoją pracę, opatrzył ją następującymi słowami: „Stare kobiety nie mogą powstrzymać śmiechu, bo wiedzą, że nie ma on ani grosza" ${ }^{18}$. Los requiebros od strony muzycznej tworzy zestaw wariacji bazujących na dwóch frazach tonadilla ${ }^{19}$, pochodzących z utworu hiszpańskiego kompozytora Blas de Laserna Nieva (1751-1816).

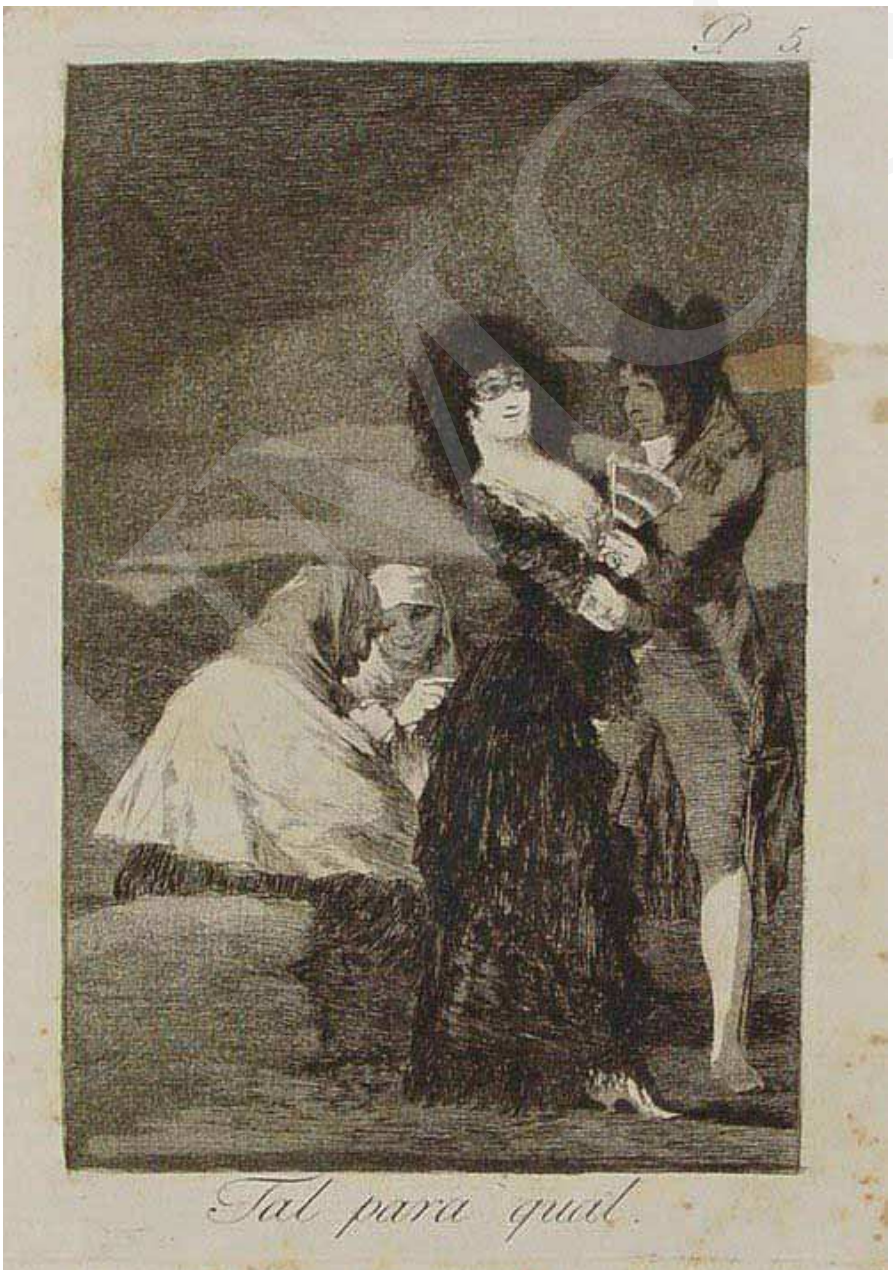

Ilustracja 1. F. Goya, Kaprys 5: Tal para qual, 1797-1798, akwaforta z akwatiną, $21,7 \mathrm{~cm} \times 15,2 \mathrm{~cm}$.

${ }^{18}$ Goya. Francisco Goya y Lucientes, Los Caprichos. Cykl osiemdziesięciu rycin ze zbiorów Towarzystwa Naukowego Płockiego. Katalog wystawy zorganizowanej przez Muzeum Lubelskie w Lublinie i Towarzystwo Naukowe Płockie, Lublin - Płock 2003, s. 43.

${ }^{19}$ Tonadilla - hiszpański gatunek literacko-muzyczny, krótka pieśń z tekstem literackim, śpiewana przy akompaniamencie gitary. 
Drugą część cyklu, zatytułowaną Coloquio en la reja - Duo de amor [Dialog w oknie - duet miłosny], stanowi blisko 12-minutowe, refleksyjne i najdłuższe ogniwo cyklu. W komentarzu autorstwa Daglasa Rivy czytamy, że Granados tworzy nastrój zawoalowanej tajemnicy wypełnionej romantyczną tęsknotą, obrazującą kobietę w jej domu podczas rozmowy z jej adoratorem przez żelazną kratę w oknie. Część trzecia cyklu, El fandango de candil [Fandango w świetle świecy], opisywana przez kompozytora jako „scena mająca być śpiewana i tańczona wolno i rytmicznie”, jest przesycona nocną, nokturnową, ale żywiołową atmosferą. Kolejna część cyklu, $Q u$ ejas, o la maja y el ruisenor [Lamenty lub „Maja i stowik”], zainspirowana piosenką ludową z Walencji, jest jednym z najbardziej poetyckich utworów hiszpańskiej muzyki fortepianowej. Granados przeprowadza tu melodię przez serię wariacji - każda z nich jest bardziej intensywna niż poprzednia, z kulminacją w cadenza, imitującą pieśń słowika. Dla następnej części Goyescas inspiracją stał się kaprys opatrzony przez Goyę numerem 10 oraz tytułem El amor y la muerte [Miłość i śmierćc. Akwafortę opatrzył artysta komentarzem: „,widzicie tutaj kochanka z Calderona, który niezdolny do wyśmiania rywala, umiera w ramionach ukochanej i traci ją przez swą zuchwałość. Nieroztropnie jest wyciągać szpadę zbyt często"20.

Muzyczny odpowiednik tej grafiki jest bardzo refleksyjny, tajemniczy, poważny; wyraża ból, nostalgiczną miłość i tragiczny jej finał - śmierć. Według Granadosa wszystkie tematy Goyescas są zjednoczone w El amor y la muerte. Środkowa część utworu bazuje na tematach z Quejas o la maja y el ruisenor oraz Los requiebros, przemieniając dramat w finale w delikatny żal. Ostatnie akordy reprezentują wyrzeczenie się radości ${ }^{21}$. Epilogo: Serenata del espectro [Epilog - serenada ducha] to szósty i skądinąd jedyny fragment suity, który nie został włączony przez Granadosa do opery o tym samym tytule. W Epilogu kompozytor wykorzystuje sekwencję Dies irae. Część siódma cyklu Goyescas, zatytułowana El pelele - Escena goyesca [Kukła-scena od Goi], odnosi się do obrazu Goi o tym samym tytule. Dzieło wykonane przez artystę przedstawia grupę kobiet podrzucających kukłę w niebo. W tej pozornie wesołej scenie ukazane zostały cztery młode i wesołe kobiety podrzucające nad rozciągniętym płótnem wypchaną kukłę imitującą mężczyznę. Groteskowy pajac stał się zabawką w rękach kobiet. Zabawie tej towarzyszy atmosfera okrucieństwa, jakie widzimy na niektórych akwafortach Goi. Wymowa dzieła - jak większości akwafort ze zbioru $\mathrm{Ca}$ prichos - wykracza daleko poza swój czas, pokonując barierę historyczną, ,wchodząc w dziedzinę uniwersalnych prawd o człowieku, ujawnia podstawowe prawa ludzkiej egzystencji, niezależnie od czasu i miejsca, penetruje tajniki ludzkiej psychiki”"22.

\footnotetext{
${ }^{20}$ Goya..., s. 48.

${ }^{21}$ Riva, op. cit., s. 3.

${ }^{22}$ I. Kossowska, Świat realny i fantasmagoria, [w:] Goya ..., s. 15.
} 
Pobrane z czasopisma Annales L - Artes http://artes.annales.umcs.pl

Data: 26/04/2023 15:49:07

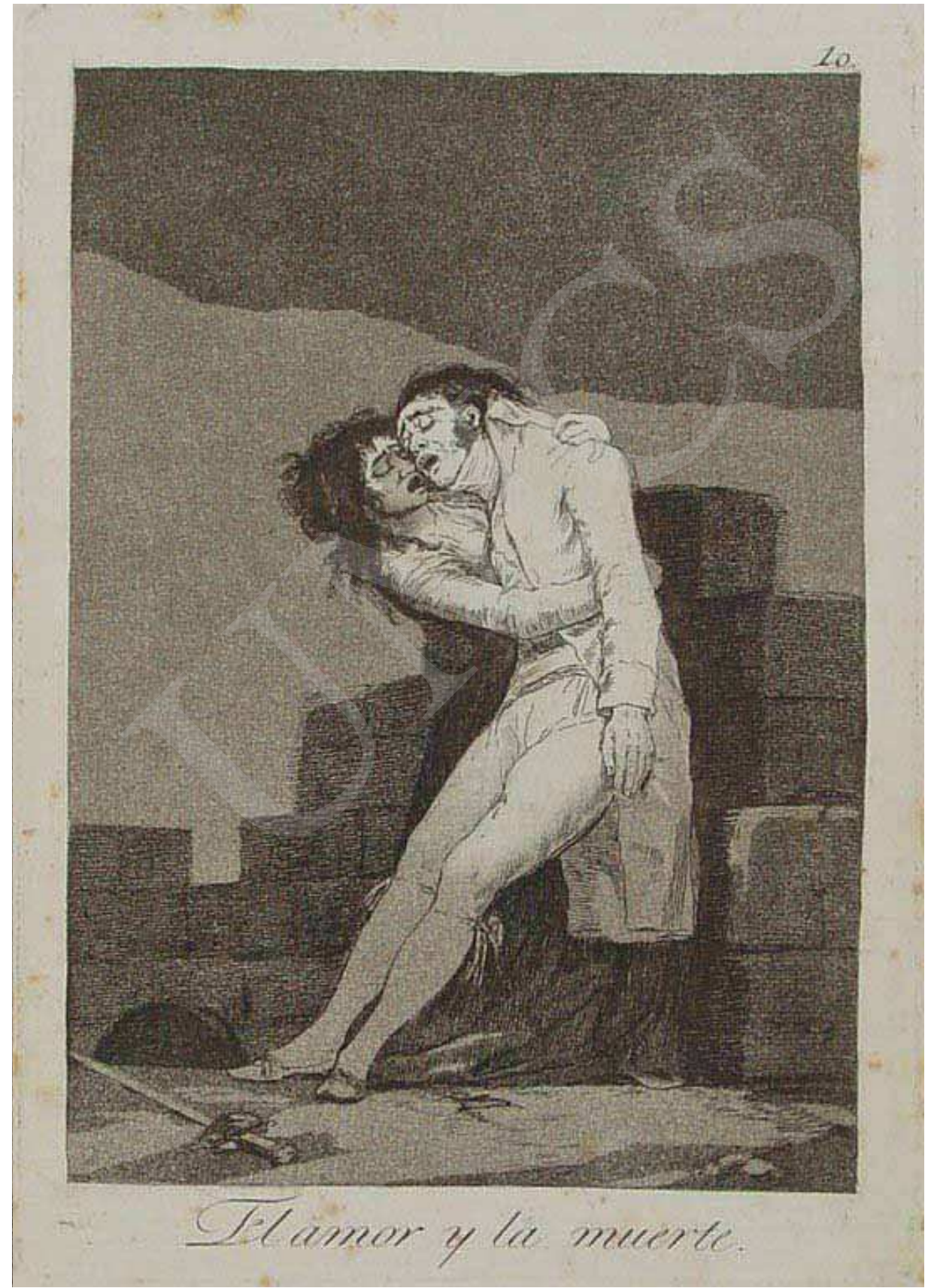

Ilustracja 2. F. Goya, Kaprys 10: El amor y la muerte, 1797-1798, akwaforta $\mathrm{z}$ akwatiną, $21,8 \mathrm{~cm} \times 15 \mathrm{~cm}$. 
Pobrane z czasopisma Annales L - Artes http://artes.annales.umcs.pl

Data: 26/04/2023 15:49:07

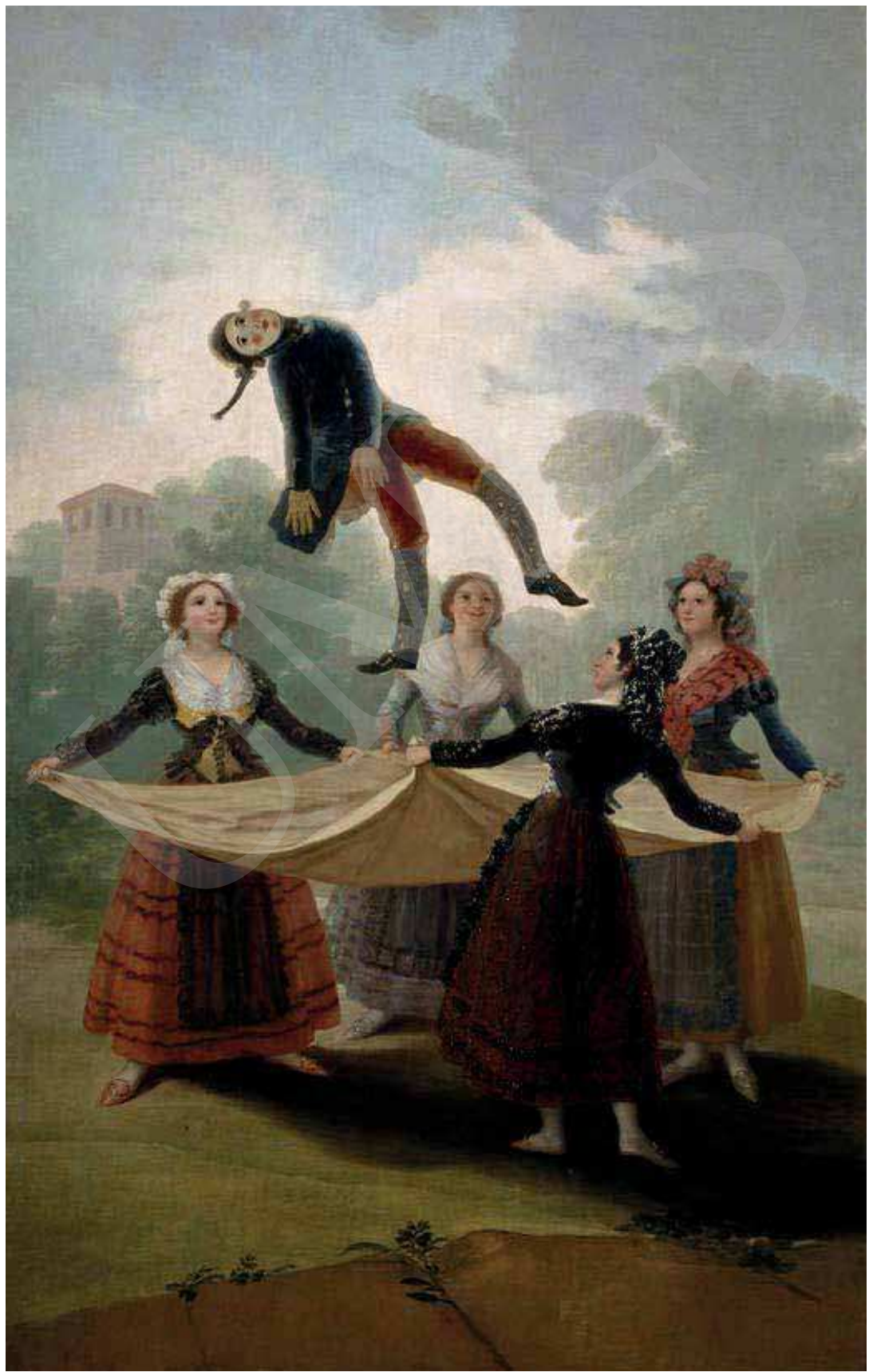

Ilustracja 3. F. Goya, Słomiana kukła, 1791-1792, olej na płótnie $267 \mathrm{~cm}$ x 160cm, Madryt, Museo del Prado, cyt. [za:] R. R. Hagen, Goya, Warszawa 2005, s. 18. 
Pobrane z czasopisma Annales L - Artes http://artes.annales.umcs.pl Data: 26/04/2023 15:49:07

Całość cyklu zamyka Serenata goyesca [Serenada w stylu Goi], która jest nieopublikowaną pracą znalezioną w archiwum w Barcelonie. Chociaż manuskrypt nie ma daty, najprawdopodobniej utwór został skomponowany około 1909 roku jako pierwszy szkic do Goyescas.

\section{Joaquin Turina}

Twórczość Joaquina Turiny, popularnego na przełomie XIX i XX wieku kompozytora, pianisty, dyrygenta, krytyka muzycznego i pedagoga, bogata jest w kompozycje inspirowane krajem ojczystym, jego regionami i miastami. To kolejny artysta spośród twórców przełomu wieków podejmujący się tworzenia narodowej muzyki hiszpańskiej. Elementy programowości i ilustracyjności uwidacznia pierwszy spośród przytaczanych tutaj utworów Turiny, Sinfonia Sevillana op. 23 (1920). Wspomnieć należy też o kompozycji kameralnej Escena andaluza op. 7 (1912) na altówkę, fortepian i kwartet smyczkowy oraz o Sonata española op. 82 (1934) na skrzypce i fortepian. Wizję antycznej Hiszpanii zawarł Turina w Recuerdos de la antiqua España op. 48, a historyczną krainę w zachodniej części Pirenejów, na pograniczu Hiszpanii i Francji, upamiętnił w Homenaje a Navarra op. 102, Ogrody andaluzyjskie ukazał w suicie fortepianowej Jardines de Andalucia op. 31 (1924). Arabski zamek znajdujący się w prowincji Kordoba w miejscowości Almodóvar del Río Turina upamiętnił w trzyczęściowej fortepianowej kompozycji z 1931 roku El Castillo de Almodóvar op. 65 (części: Siluenta nocturna, Evocacion medival, A plena luz). Kilka utworów na fortepian poświęcił miastu Sewilla i jej zabytkom, m.in. Mujeres de Sevilla op. 89, Por las calles de Sevilla op. 96, La leyenda de la Giralda op. 40. Turina pozostawił też liczne pieśni na głos i fortepian, spośród których warto wymienić cykl siedmiu utworów na sopran i fortepian Canto a Sevilla op. 37 (1930) oraz cykl dziewięciu utworów na sopran, fortepian i kwartet smyczkowy Las musas de Andalucia op. 93 (1942). Skomponował również, mimo iż był pianistą, „ojczyste” dzieła gitarowe, m.in.: Sevillana op. 29 (1923), Fandanguillo op. 36 (1925), Homenaje a Tarrega op. 69 (1932) - utwór w iście hiszpańskim stylu, napisany w hołdzie twórczości Francisco Tárregi.

Turina czerpał z muzycznych tradycji południa Hiszpanii - Andaluzji i innych regionów. W jego kompozycjach słyszymy elementy charakterystyczne dla romantyzmu, obok tego także impresjonizmu, szczególnie w muzyce fortepianowej. Utwory napisane na gitarę w pełni wykorzystują możliwości brzmieniowe instrumentu. Joaquin Turina - wraz z Albénizem i Granadosem - kształtował narodowy nurt muzyki hiszpańskiej. 


\section{Manuel de Falla}

Twórczość Manuela de Falli - jednego z najwybitniejszych kompozytorów w dziejach muzyki hiszpańskiej - wywodzi się z rodzimej muzyki ludowej, w szczególny zaś sposób łączy się z folklorem andaluzyjskim. Najcenniejszym w muzyce de Falli, by zacytować Bogusława Schaeffera, jest „sposób asymilacji i przetwarzania elementów folklorystycznych, zespalania ich z indywidualnymi koncepcjami formalno-wyrazowymi, daleki dosłownemu cytowaniu materiału ludowego"23. Schaeffer na łamach swojego kompendium o kompozytorach XX wieku stwierdza, iż o kierunku jego folklorystycznych zainteresowań zadecydowało zetknięcie się na starcie kariery kompozytorskiej ze znakomitym badaczem hiszpańskiej muzyki ludowej, Filipem Pedrellem, który - jak stwierdzi de Falla po latach - nadał jego twórczości zdecydowany i wyraźny kierunek ${ }^{24}$. Spośród jego stosunkowo niedużej liczby kompozycji orkiestrowych, kameralnych, wokalnych i wokalno-instrumentalnych tylko kilka w tytule posiada nazwy geograficzne. Są to dzieła pochodzace z lat 1896-1906: Serenata andaluza oraz Cuatro piezas españolas, cykl obejmujący cztery utwory - Andaluza, Cubaña, Aragoñesa, Montañesa. Spośród kompozycji wokalnych na uwagę zasługuje siedem pieśni hiszpańskich na głos i fortepian z 1914 roku; trzecia z nich opatrzona została tytułem Asturias. W 1927 roku Falla skomponował ponadto Soneto a Cordoba na głos i harfę (lub fortepian), w roku 1933 zaś utwór na chór mieszany a cappella - Ballada de Mallorca.

Trzy dzieła Manuela de Falli w szczególnie wyraźny sposób odnoszą się do regionu Andaluzji: balety El amor brujo [Czarodziejska miłość] i El sombrero de tres picos [Trójgraniasty kapelusz] oraz kompozycja orkiestrowa Noches en los jardines de España [Noce w ogrodach Hiszpanii].

Balet Czarodziejska miłość, noszący podtytuł Cygańskie sceny z Andaluzji, czerpie ze specyfiki muzyki południa Hiszpanii i elementów muzyki cygańskiej. Na szczególne podkreślenie zasługuje tu Danza ritual del fuego [Taniec ognia], znany także z transkrypcji fortepianowej. Rodzima kraina kompozytora oraz cechy jej bogatego folkloru odezwały się również w balecie Trójgraniasty kapelusz. Koncertowe opracowania tego baletu ujmowane są zwykle w dwóch suitach. Finałowy taniec aragoński jota - opracowany na podstawie ludowego oryginału w porywającej oprawie instrumentalnej - to najefektowniejsza część drugiej suity, zamykająca kompozycję.

${ }^{23}$ T. Chylińska, S. Haraschin, B. Schaeffer, Przewodnik koncertowy, Kraków 1991, s. 299.

${ }^{24}$ B. Schaeffer, Kompozytorzy XX wieku, Kraków 1990, s. 100. 
Trzyczęściowa impresja symfoniczna na fortepian i orkiestrę pod tytułem Noce w ogrodach Hiszpanii powstała podczas pobytu Manuela de Falli w Paryżu w latach 1909-1915. Choć dzieło nie posiada żadnego poetyckiego programu, to tytuły poszczególnych części zdają się uzewnętrzniać wrażenia i uczucia kompozytora; podczas paryskiego okresu mówił on: „byłem tak daleko Hiszpanii, że owe noce odmalowałem może piękniejszymi, niż są w rzeczywistości..."25. Generali$f e$ - tytuł pierwszego ogniwa cyklu - to nazwa letniej rezydencji arabskich władców leżącej nieopodal Granady; muzyka ilustruje tu atmosferę dusznej, letniej nocy, rozbrzmiewa w niej wiele andaluzyjskich motywów o orientalnym charakterze i dźwięków imitujących gitarę. Cześć druga to Taniec w oddali. Powtarzane motywy - naprzemiennie ze zróżnicowaną dynamiką - sprawiają w słuchaczu wrażenie przybliżania i oddalania się obrazów tytułowego ogrodu, z energicznym finałem, przechodzącym w trzecią część - W ogrodach Sierra de Cordoba, którą wieńczy refleksyjna kantylena skrzypiec, przywołująca piękne, bajkowe ogrody Alkazaru w Kordobie, założone w orientalnym stylu mauretańskim.

***

Różnorodność i kontrasty, które stanowią o specyficznym charakterze Hiszpanii, dają się zauważyć w wielu miastach tego kraju, a kultury arabska, żydowska i chrześcijańska - zarówno w swoich czystych przejawach, jak i tych będących rezultatem wzajemnych wpływów - tworzą dorobek historyczny i artystyczny trwale obecny do naszych czasów. Nadając utworom tytuły związane z ważnymi miejscami swojej ojczyzny - co istotne, z uwzględnieniem zakorzenionych w nich fenomenów kulturowych i muzycznych (folklor, tańce, pieśni, instrumentarium), kompozytorzy hiszpańscy, poprzez muzyczną ,geografię”, utrwalili w pamięci kolejnych pokoleń „mapę” swojego kraju, zapewnili jednocześnie muzyce hiszpańskiej trwałe miejsce w kulturze światowej.

\section{SUMMARY}

In the musical works of Spanish composers of the 19th and 20th centuries we can perceive a clearly distinguished trend of works for which inspiration sources emerged from the geographic-cultural topoi of their native country. The names of regions in Spain (e.g. Asturias, Castile, Andalusia), its towns (e.g. Granada, Cadiz, Cordoba) frequently appear in the titles of these types of work in close connection with various important

\footnotetext{
${ }^{25}$ Chylińska, Haraschin, Schaeffer, op.cit., s. 302.
} 
historical-cultural phenomena, e.g. with the paintings of Francisco Goya). We see it in the compositions of leading Spanish composers of the late 19th and the beginning of the 20th centuries: Francisco Tárrega (1852-1909), Isaac Albéniz (1860-1949), Enrique Granados (1867-1916), Manuel de Falla (1876-1946), and Joaquin Turina (1882-1949). In the article, the author discusses inter alia: Wspomnienia z Alhambry [Memories of Alhambra] by Tárrega, I Suita hiszpańska [Spanish Suite no. 1] and Iberia by Albéniz, Goyescas by Granados, Noce w ogrodach Hiszpanii [Nights in the Gardens of Spain] by de Falla. By giving their works the titles connected with important places of their motherland, including also various cultural and musical phenomena rooted in them (folklore, dances, songs, instrumentation), the Spanish composers commemorated "the map" of their country in the memories of subsequent generations, and at the same time, ensured Spanish music a constant place in the world culture. 